\title{
WPLYW EUROPEIZACJI PRAWA NA STANDARDY OCHRONY JEDNOSTKI PRZED WLADZĄ DYSKRECJONALNĄ ORGANÓW ADMINISTRACJI PUBLICZNEJ
}

\section{WPROWADZENIE}

Przenikanie norm prawa europejskiego do polskiego porządku prawnego trwa nieprzerwanie od ponad dekady. Jeszcze przed momentem przystapienia w 2004 r. Polski do Unii Europejskiej jako element konieczny integracji wskazywało się dostosowanie polskiego systemu prawnego do unijnego. Wejście w życie traktatu akcesyjnego ${ }^{1}$ wymogło szereg zmian, w tym konieczność ciągłego ujednolicania krajowego porządku prawnego.

Proces majacy na celu dostosowanie polskiego systemu prawnego do unijnego, szeroko opisywany w literaturze przedmiotu, przyjęło się nazywać mianem europeizacji ${ }^{2}$ prawa polskiego. Należy zauważyć, że „europeizacja” jest pojęciem niezwykle szerokim, każdorazowo definiowanym nieco odmiennie na użytek konkretnego opracowania. Najłatwiej będzie opisać europeizację przez pryzmat trzech podstawowych procesów, jakie maja miejsce w jej ramach, tj.: unifikację, upodobnienie i harmonizację (zbliżenie) ${ }^{3}$. Nie wdajac się w nadmierne szczegóły, należy wskazać, że unifikacja polega na wprowadzeniu do polskiego porządku prawnego tekstu prawa wspólnotowego bez żadnych zmian. Upodobnienie zaś nie wymaga zastapienia prawa krajowego prawem unijnym, ale jedynie wprowadzenia takich regulacji prawnych, które - jak określił Marek Zirk-Sadowski - „z tym samym zakresem zastosowania normy wiążą te same zakresy normowania"4. Natomiast harmonizacja, w przeciwieństwie do dwóch poprzednich terminów, jest pojęciem wykraczającym poza ramy prawne. Harmonizacja bowiem nie polega wyłącznie na działalności pra-

${ }_{1}^{1}$ Traktat o przystapieniu Rzeczypospolitej Polskiej do Unii Europejskiej podpisany 16 kwietnia 2003 r. w Atenach, Dz. U. 2004, Nr 90, poz. 864.

${ }^{2}$ Pojęcie „europeizacja prawa” zostało wprowadzone przez J. Łętowskiego, Rada Europy o postepowaniu administracyjnym, w: Problemy prawa publicznego, Lublin 1993, s. 93.

${ }^{3}$ Podział za: J. Jabłońska-Bonca, Źródła prawa Wspólnot Europejskich, Gdańsk 1993, s. 73 i n.

${ }^{4}$ M. Zirk-Sadowski, Filozoficzno-teoretyczne aspekty harmonizacji polskiego porzqdku prawnego z europejskim prawem wspólnotowym, w: M. Matey-Tyrowicz (red.), System prawa RP w procesie europeizacji, Warszawa 2002, s. 15. 
wodawczej, ale wskazuje na równie istotną rolę praktyki, doktryny oraz świadomości prawnej obywateli ${ }^{5}$.

Metodą właściwą dla prawa administracyjnego, w interesujacym nas zakresie korzystania przez organy administracji publicznej z władzy dyskrecjonalnej, jest przede wszystkim upodobnienie i harmonizacja. Metody te sa właściwe również dla prawa i postępowania administracyjnego w ogólności. W doktrynie podkreśla się, że w tej dziedzinie prawa państwa członkowskie obowiąuje „autonomia proceduralna”, która doznaje jednak coraz większych ograniczeń, np. w zakresie postępowania celnego, które jest prowadzone na podstawie unijnego kodeksu celnego ${ }^{6}$.

Pisząc o europeizacji prawa administracyjnego, należy więc szukać przede wszystkim wyznaczników w postaci zaleceń, rekomendacji i opinii tworzących określone standardy prawne.

\section{POJĘCIE WKADZY DYSKRECJONALNEJ NA GRUNCIE POLSKIEGO PRAWA ADMINISTRACYJNEGO}

Analiza uregulowań unijnych i wynikających z nich standardów w zakresie ochrony jednostki przed działaniami organów administracji publicznej podejmowanymi w ramach władzy dyskrecjonalnej wymaga omówienia samego pojęcia władzy dyskrecjonalnej, które wykształciło się w literaturze przedmiotu.

Niewątpliwie kwestia istnienia władzy dyskrecjonalnej, jej zakresu oraz możliwej do przeprowadzenia kontroli działań podejmowanych w jej ramach należy do najistotniejszych na gruncie prawa administracyjnego ${ }^{7}$. Samo przyznanie władzy dyskrecjonalnej organom administracji publicznej stało się naturalna konsekwencja wynikajacca z istoty prawa administracyjnego ${ }^{8}$. Ta gałąź prawa cechuje się wewnętrzną niespójnością polegająca z jednej strony na konieczności realizacji norm ustawowych, a z drugiej - na konieczności posiadania pewnej swobody działania pozwalajaccej na kształtowanie polityki administracyjnej. Dyskrecjonalność jest instrumentem prawnym, który zapewnia elastyczność prawa, jednocześnie respektując zasadę legalizmu. Zatem umożliwia realizację polityki administracyjnej, czyniąc to w ramach ustalonego porządku prawnego. Działanie dyskrecjonalne tym różni się od dowolnego, że do działania dyskrecjonalnego organ musi zostać wyraźnie upoważniony przez prawodawcę. Brak unormowania prawnego (sytuacja luki prawnej) nie może

5 Ibidem, s. 19.

${ }_{6}$ Rozporządzenie Parlamentu Europejskiego i Rady (UE) nr 952/2013 z 9 października 2013 r. ustanawiające unijny kodeks celny (Dz. Urz. UE L 269 z 10 października 2013 r.).

${ }^{7}$ Nadmienić należy, że to pojęcie jest szeroko dyskutowane także w innych systemach prawnych. Swoboda, jaką posiadają organy administracyjne, działając w ramach władzy dyskrecjonalnej, bywa porównywana do swobody ustawodawcy - S. G. Breyer et al., Administrative Law and Regulatory Policy. Problems, Text and Cases, Aspen Publishers 2006, s. 141.

8 W literaturze zagranicznej wskazuje się wręcz na nieuchronność istnienia dyskrecjonalności - P. M. Shane, The rule of law and the inevitability of discretion, „Harvard Journal of Law and Public Policy" 2013, nr 1, s. 21-28. 
być interpretowany w demokratycznym państwie prawnym jako przyzwolenie na podejmowanie działań o charakterze dyskrecjonalnym ${ }^{9}$. W doktrynie podkreśla się, że każda działalność organów administracyjnych musi znajdować podstawy prawne, a ściślej - podstawy ustawowe ${ }^{10}$. Wobec powyższego granica dopuszczalnej swobody działania organu w świetle związania administracji publicznej prawem powinna być właśnie zasada legalizmu.

W literaturze przedmiotu wielokrotnie podejmowano próby zdefiniowania istoty władzy dyskrecjonalnej. Jedną z bardziej udanych prób podją Leszek Leszczyński (w tekście zawartym w monografii pokonferencyjnej poświęconej zagadnieniu dyskrecjonalności w prawie). Autor stwierdził, że dyskrecjonalność w ogólnym zarysie oznacza swobodę decyzyjną mieszczącą się co do jej przejawów i zakresu w ramach określonego porządku prawnego (w tym w jego założeniach aksjologicznych), dotycząca wszystkich elementów składowych procesu decyzyjnego stosowania prawa ${ }^{11}$. Niewątpliwie ta definicja jest bliska ujęcia istoty dyskrecjonalności, jednakże nie jest ona definicją pełna, dotyczy bowiem tylko dyskrecjonalności na poziomie stosowania prawa i pomija dyskrecjonalność, jaka posiadają organy administracji publicznej w sferze stanowienia prawa, m.in. w zakresie, w jakim moga wydawać rozporządzenia oraz akty prawa miejscowego. Jednak ze względu na tematyke niniejszego artykułu dyskrecjonalność będzie rozumiana waskko: jako swoboda działania mieszcząca się wyłącznie w sferze stosowania prawa, podobnie jak to jest rozumiane w prawie unijnym.

Definicja Leszczyńskiego zatem będzie użyteczna na potrzeby niniejszego artykułu, jednak nie ze wszystkimi jej elementami należy się zgodzić. Przede wszystkim dyskrecjonalność nie dotyczy wszystkich elementów składowych procesu stosowania prawa, gdyż nie na wszystkich etapach jego stosowania jest możliwe pozostawienie przez prawodawcę swobody działania organowi administracyjnemu ${ }^{12}$. Po wtóre, stwierdzenie, że „dyskrecjonalność w ogólnym zarysie oznacza swobodę decyzyjną”, jest zbyt wąskie, w ramach władzy dyskrecjonalnej bowiem na pewno mieszcza się tzw. luzy interpretacyjne, które z kolei nie należą do luzów decyzyjnych, gdyż znajdują się one na różnych etapach stosowania prawa.

Należałoby zatem zdefiniować dyskrecjonalność szerzej, jako pozostawiona przez prawodawcę organowi administracyjnemu swobodę działania, mieszczącą się co do jej zakresu w ramach określonego porządku prawnego oraz w jego założeniach aksjologicznych, dotyczącą wybranych etapów procesu stosowania

${ }^{9}$ Z. Duniewska, Istota i granice dyskrecjonalnej wtadzy administracyjnej $w$ świetle standardów europejskich, „Studia Prawno-Ekonomiczne” 1999, z. 59, s. 22.

${ }_{10}$ Por. Z. Leoński, Zmiany materialnego prawa administracyjnego w III RP a ochrona praw jednostki, w: idem (red.), Rola materialnego prawa administracyjnego a ochrona praw jednostki, Poznań 1998, s. 9.

${ }^{11}$ L. Leszczyński, Dyskrecjonalność a jednolitość stosowania prawa. Rola argumentu per rationem decidendi, w: W. Staśkiewicz, T. Stawecki (red.), Dyskrecjonalność w prawie, Warszawa 2010 , s. 137.

12 Szerzej na ten temat: M. Jędrzejczak, Elementy dyskrecjonalności organu administracyjnego na poszczególnych etapach stosowania prawa, „Przegląd Prawniczy, Ekonomiczny i Społeczny” 2013, nr 2, s. 4 i n. 
prawa. Należy zauważyć, że w takim ujęciu do przejawów władzy dyskrecjonalnej należy zaliczyć zarówno uznanie administracyjne, interpretację pojęć niedookreślonych, jak i wszystkie inne luzy, które posiada organ podczas procesu stosowania prawa. Nie można zatem utożsamiać władzy dyskrecjonalnej na poziomie stosowania prawa jedynie z uznaniem administracyjnym, co czynią niektórzy przedstawiciele doktryny ${ }^{13}$. Uznanie jest jednym z rodzajów luzów decyzyjnych w ramach dyskrecjonalności.

\section{REGULACJE UNIJNE ZWIAZZANE Z PROBLEMATYKĄ WŁADZY DYSKRECJONALNEJ ORGANÓW ADMINISTRACJI PUBLICZNEJ}

Istnieją znaczne różnice pomiędzy systemami postępowania administracyjnego państw europejskich ${ }^{14}$. Odrębności te dotyczą z jednej strony sposobu ukształtowania reguł procedury i leżących u ich podstaw idei, z drugiej natomiast przesądził o nich odmienny zakres podjętych zabiegów unifikacyjnych i przeprowadzonych kodyfikacji. Z tego względu unijne regulacje prawne pozostają na wysokim poziomie ogólności, który ma na celu raczej ustanowienie pewnych standardów niż norm prawnych.

Standardy unijne w zakresie prawa administracyjnego służą przede wszystkim ochronie praw jednostki. Słusznie zauważył już w latach dziewięćdziesiątych XX w. Janusz Łętowski, że Rada Europy uchwala konwencje, wydaje liczne dyrektywy i zalecenia, których przedmiotem jest głównie sfera określana jako „prawa człowieka”, a przede wszystkim stosunki na linii obywatel-państwo ${ }^{15}$. Owo skoncentrowanie prawodawcy unijnego na jednostce i zapewnieniu jej ochrony jest widoczne również obecnie.

Konieczność zapewnienia ochrony obywatelowi szczególnie mocno uwidacznia się w zakresie rozstrzygnięć podejmowanych w ramach dyskrecjonalności. Kwestia posiadania władzy dyskrecjonalnej przez organy administracyjne jest niewątpliwie jednym z najbardziej spornych problemów w nauce i praktyce krajowego oraz europejskiego prawa administracyjnego. Samo jej przyznanie, choć nieodzowne w procesie stosowania prawa, może prowadzić do nadużyć ze strony organów administracji publicznej oraz arbitralności podejmowanych rozstrzygnięć. Nie ulega wątpliwości, że władza dyskrecjonalna przyznana organom administracyjnym wzmacnia także nierówność stron stosunku administracyjnoprawnego.

W odpowiedzi na powyższe zagrożenia, dostrzegalne również dla prawodawcy unijnego, zostały stworzone pewne standardy służące ochronie jednostek. Standardy te wynikają z tzw. soft law $w^{16}$. Nie mają one więc charakteru

\footnotetext{
${ }^{13}$ Por. m.in. Z. Duniewska, op. cit., s. 11, która pisząc o władzy dyskrecjonalnej, utożsamia ją z uznaniem administracyjnym.

${ }^{14} \mathrm{O}$ różnorodności postępowań administracyjnych w wybranych jedenastu krajach europejskich pisano w: Z. Kmieciak (red.), Postepowanie administracyjne w Europie, Warszawa 2010.

15 J. Łętowski, op. cit., s. 93-94.

16 M. Jaśkowska, Europeizacja prawa administracyjnego, „Państwo i Prawo” 54, 1999, z. 11, s. 21 .
} 
prawnie wiążącego, o czym przesądza art. 288 Traktatu o funkcjonowaniu Unii Europejskiej ${ }^{17}$, niemniej jednak powinny być brane pod uwagę podczas tworzenia prawa krajowego i z całą pewnością wpływają one na praktykę administracyjna ${ }^{18}$.

Źródłem tych standardów są w głównej mierze trzy akty unijne: rekomendacja dotycząca wykonywania dyskrecjonalnych kompetencji administracji ${ }^{19}$, która stanowi rozwinięcie wcześniej uchwalonej rezolucji o ochronie jednostki w sprawach rozstrzyganych aktami organów administracji ${ }^{20}$, oraz Europejski kodeks dobrej praktyki administracyjnej ${ }^{21}$ (zwany również Europejskim kodeksem dobrej administracji).

\section{Rekomendacja Komitetu Ministrów Rady Europy nr R (80)2 z 11 marca 1980 r. dotycząca wykonywania dyskrecjonalnych kompetencji administracji}

Rekomendacja ta jest niewątpliwie najważniejszym aktem unijnym w zakresie stosowania władzy dyskrecjonalnej, gdyż odnosi się do niej wprost. Akt ten definiuje pojęcie władzy dyskrecjonalnej oraz ustanawia szereg standardów, które - jak podkreśla się w literaturze przedmiotu - mogą być stosowane również do pozostałych aktów administracyjnych ${ }^{22}$. Rekomendacja została opracowana przez Komitet Ekspertów do spraw Prawa Administracyjnego w oparciu o studium porównawcze prawa stanowionego, praktyki administracyjnej oraz orzecznictwa państw członkowskich ${ }^{23}$.

W załączniku do rekomendacji wskazano, że przez „kompetencję dyskrecjonalną" (pouvoir discretionnaire) rozumie się kompetencję, która przyznaje władzy administracyjnej „pewien zakres swobody podjęcia decyzji, pozwalając jej dokonywać wyboru spośród wielu rozwiązań prawnie uzasadnionych takiego, które wydaje się jej najbardziej stosownym" ${ }^{24}$. Interpretacja powyższego zapisu pozwala na stwierdzenie, że w tym akcie unijnym odmiennie rozumie się pojęcie dyskrecjonalności. Władza dyskrecjonalna jest utożsamiona z polskim pojęciem uznania administracyjnego ${ }^{25}$. Prawodawca unijny zauważa w czę-

17 Wersja skonsolidowana Traktatu o funkcjonowaniu Unii Europejskiej, Dz. Urz. UE C 83/47.

18 L. Leszczyński, Europejski Kodeks Dobrej Administracji a zasady polskiej procedury administracyjnej, w: I. Rzucidło (red.), Europeizacja prawa administracyjnego, Lublin 2011, s. 13.

${ }^{19}$ Rekomendacja nr R (80)2 Komitetu Ministrów Rady Europy dotycząca wykonywania dyskrecjonalnych kompetencji administracji przyjęta 11 marca 1980 r. na 316 posiedzeniu wiceministrów.

${ }^{20}$ Rezolucja Komitetu Rady Ministrów Europy nr (77)31 z 28 września 1977 r. o ochronie jednostki w sprawach rozstrzyganych aktami organów administracji. Tekst rezolucji wraz z memorandum wyjaśniającym zamieszczono w: Principles of Administrative Law Concerning the Relations between Administrative Authorities and Private Persons, Strasbourg 1996, s. 236-241.

${ }^{21}$ Europejski kodeks dobrej administracji przyjęty przez Parlament Europejski 6 września $2001 \mathrm{r}$.

${ }^{22}$ A. Skóra, Polska procedura administracyjna w świetle standardów europejskich, „Przegląd Prawa Europejskiego" 1999, nr 1, s. 63.

${ }^{23}$ Z. Duniewska, op. cit., s. 17.

${ }^{24}$ Dział I załącznika do rekomendacji nr R (80)2.

25 Por. definicję uznania administracyjnego stworzoną przez M. Mincer, Uznanie administracyjne, Toruń 1983, s. 63. 
ści poświęconej rozważaniom ogólnym, że postanowienia rekomendacji nie mają zastosowania wobec aktów administracyjnych, w których ustawodawca przyznaje organom kompetencję prawną zwaną nieokreślona, a sens takiej kompetencji władza administracyjna powinna zidentyfikować samodzielnie każdorazowo na użytek konkretnego przypadku ${ }^{26}$. Polskiej nauce prawa administracyjnego nie jest znane pojęcie „kompetencja nieokreślona”, jednak z opisu można wnioskować, że chodzi o wszystkie te sytuacje, w których organ dysponuje luzem interpretacyjnym związanym z użyciem przez prawodawcę pojęć niedookreślonych $\mathrm{w}$ tekście prawnym. Zatem na gruncie omawianego aktu unijnego interpretacja pojęć niedookreślonych nie będzie częścią władzy dyskrecjonalnej wyłącznie ze względu na wspomnianą w rekomendacji trudność w wypracowaniu dla niej jednolitych standardów.

Do podstawowych zasad, którymi powinny kierować się organy administracyjne, działając $\mathrm{w}$ ramach władzy dyskrecjonalnej, zgodnie $\mathrm{z}$ rekomendacja należa:

1) kierowanie się wyłącznie celem przez wzgląd, na który kompetencja została przyznana,

2) obiektywność i bezstronność,

3) równość wobec prawa,

4) proporcjonalność,

5) rozsądny termin załatwienia sprawy,

6) stosowanie ogólnych dyrektyw administracyjnych w sposób konsekwentny i stały, zawsze biorąc pod uwagę szczególne okoliczności każdego przypadku.

Cel, o którym mowa w punkcie pierwszym, jest celem ustawowym. Prawodawca unijny podkreśla, że cel taki powinien być skonstruowany w sposób możliwie jasny. Wskazane byłoby więc określenie tego celu w samej normie prawnej upoważniającej do podjęcia działań dyskrecjonalnych. Wymagania te w polskim prawie administracyjnym spełniają tzw. dyrektywy wyboru konsekwencji prawnych, które zawierajacc wskazówki co do tego, jak należy dokonać wyboru (jaki mieć na względzie cel), jednocześnie ograniczają swobodę działania organu ${ }^{27}$. Jeśli cel ustawowy nie jest wyraźnie sprecyzowany, organ powinien działać w celu o podstawowym znaczeniu dla całej administracji publicznej, czyli w interesie publicznym.

Zasady obiektywności i bezstronności wymagają od organu uwzględnienia wszystkich istotnych elementów sprawy, a więc wymagają rzetelnie przeprowadzonego postępowania dowodowego w zakresie analizy stanu faktycznego oraz rzetelnej analizy stanu prawnego. Powyższe wymogi odnośnie do postępowania dowodowego wydają się spełnione na gruncie polskiego postępowania administracyjnego. Stanowi o tym art. 10 Kodeksu postępowania administracyjnego ${ }^{28}$, który umożliwia stronom czynny udział w każdym stadium postępowania, oraz przepisy rozdziału czwartego znajdującego się $\mathrm{w}$ dziale drugim. Istotny jest zwłaszcza art. 77 k.p.a., który nakłada na organy obowia-

\footnotetext{
${ }^{26}$ Dział IV pkt 12 załącznika do rekomendacji nr R (80)2.

${ }^{27}$ Szerzej na ten temat: M. Jędrzejczak, Koncepcje ograniczajace swobode organu $w$ ramach uznania administracyjnego, „Przegląd Prawniczy, Ekonomiczny i Społeczny” 2012, nr 3, s. 11 i n.

${ }^{28}$ Ustawa z 14 czerwca 1960 r. - Kodeks postępowania administracyjnego, t.jedn.: Dz. U. 2013, poz. 267 (dalej jako: k.p.a.).
} 
zek wszechstronnego rozpatrzenia materiału dowodowego w sprawie. Z kolei zasadę bezstronności gwarantuje art. 24 k.p.a. stanowiący o możliwości wyłaczenia pracownika lub organu od udziału w postępowaniu. Mimo że ramy prawne spełnienia zasad obiektywności i bezstronności sa zapewnione, ich realizacja będzie zależna od prawidłowości ich zastosowania. Podkreśla się, że do najczęstszych uchybień w postępowaniu administracyjnym należą właśnie te $\mathrm{w}$ zakresie postępowania dowodowego ${ }^{29}$.

Kolejna z zasad podstawowych to zasada równości wobec prawa, której głównym celem jest zapobieżenie traktowaniu dyskryminacyjnemu. Oznacza to, że osoby znajdujace się w takiej samej sytuacji powinny być traktowane podobnie. W tym kontekście wyraźnie podkreśla się, że dyskrecjonalność nie może wiązać się z dowolnością podejmowanych rozstrzygnięć. Odstępstwa od tej zasady są możliwe jedynie, jeśli odmienność traktowania opiera się na motywach rozsądnych, mogacych ją usprawiedliwiać w sposób obiektywny przez wzgląd na realizowany $\operatorname{cel}^{30}$. Prawu unijnemu jest znane pojęcie „dyskryminacja pozytywna”, która pozwala na odstępstwo od komentowanej zasady ${ }^{31}$. W polskim porządku prawnym zasada równości wobec prawa wyrażona jest na poziomie konstytucyjnym (art. 32 Konstytucji RP).

Zasada proporcjonalności w odniesieniu do prawa administracyjnego nakazuje organom administracyjnym rozstrzygać sprawy, mając na względzie zapewnienie rozsądnego stosunku między interesem publicznym a interesami jednostek. W sposób szczególny podkreśla ona, że organy, które dysponują kompetencją dyskrecjonalna, nie mogą nakładać na jednostkę ograniczeń nadmiernych w stosunku do realizowanego celu. W komentarzu do rekomendacji zaznaczono, że zasada ta jest znana w większości państw europejskich, nawet jeśli jej treść nie jest wprost wyrażona w przepisach prawnych. Zasada proporcjonalności jest kolejną z zasad wyrażonych implicite w Konstytucji RP (art. 31 ust. 3).

Zachowanie rozsądnego terminu załatwiana sprawy jest pewnym postulatem ogólnym, który powinien odnosić się do załatwiana wszystkich spraw, nie tylko tych o charakterze dyskrecjonalnym. Samo pojęcie rozsądnego terminu nie jest łatwo definiowalne. Ocena „rozsądności” terminu każdorazowo zależy od szeregu czynników, np. stopnia zawiłości sprawy. Na gruncie europejskim w określeniu tego terminu pomocne okazuje się orzecznictwo Europejskiego Trybunału Praw Człowieka ${ }^{32}$, z kolei w prawie polskim za rozsądny uznaje się termin, w którym organ załatwił sprawę bez zbędnej zwłoki (art. 35 k.p.a.). Zbędna zwłoka to taka, która wynika z nieuzasadnionych odstępów czasu między poszczególnymi czynnościami dokonywanymi przez organ, błędnymi działaniami organu powodujaccymi przewlekłość postępowania lub stanu cał-

${ }_{29}$ Por. http://prawo.e-katedra.pl/zdaniem-prawnika/4232-mozliwe-uchybienia-przepisom-kpa-jako-podstawa-skargi-do-wsa, odczyt z 23 września 2014 r.

${ }^{30}$ Komentarz do załącznika do rekomendacji nr R (80)2 Komitetu Ministrów Rady Europy dotyczącej wykonywania dyskrecjonalnych kompetencji administracji przyjętej 11 marca 1980 r. na 316 posiedzeniu wiceministrów.

31 Np. kwestia parytetów dla kobiet.

32 Por. sprawy: König v. Niemcy, 1978 r.; Pretto i inni v. Włochy, 1979 r.; Dobbertin v. Francja, 1993 r.; Gibas v. Polska, 1996 r. 
kowitej bezczynności organu ${ }^{33}$. Na zachowanie opisywanego terminu oprócz stopnia skomplikowania danej sprawy może wpływać także zachowanie samego obywatela i organów prowadzących postępowanie (np. wspomniane pozostawanie w bezczynności). Z tego względu niezwykle ważna jest możliwość zaskarżenia do sądu administracyjnego nie tylko działań, ale również bezczynności organu.

Stosowanie ogólnych dyrektyw administracyjnych, jak zostało wyjaśnione $\mathrm{w}$ komentarzu zawartym $\mathrm{w}$ rekomendacji, polega na przestrzeganiu pewnej stałej i konsekwentnej praktyki administracyjnej, która z jednej strony zmierza ku popieraniu przewidywalności i bezpieczeństwa, ale z drugiej - podkreśla też konieczność indywidualnego badania w każdym przypadku szczególnych okoliczności sprawy. Termin „ogólne dyrektywy administracyjne” obejmuje akty wydawane w sferze wewnętrznej administracji publicznej. Będą to zarówno bezpośrednie instrukcje służbowe kierowane przez przełożonego do danego urzędnika, jak i pewne ustalone praktyki, które powinny być stosowane w przedmiotowo podobnych sytuacjach faktycznych oraz inne środki administracyjne o charakterze wewnętrznym. Co do zasady organy powinny stosować ogólne dyrektywy administracyjne w sposób szczególnie konsekwentny, gdy podejmuja rozstrzygnięcia dyskrecjonalne. W rekomendacji podkreśla się, że treść takich dyrektyw powinna być podana do publicznej wiadomości albo przynajmniej zakomunikowana zainteresowanemu, który tego żąda, zarówno przed podjęciem rozstrzygnięcia, jak i po jego podjęciu. W praktyce oznaczałoby to konieczność udzielenia swoistej promesy wydania rozstrzygnięcia o określonej treści $\mathrm{w}$ oparciu o ustalone $\mathrm{w}$ danym urzędzie praktyki, znajdujące swój wyraz w aktach wewnętrznie obowiązujących. W niektórych krajach obywatele mogą powoływać się na ogólną dyrektywę administracyjną dla zakwestionowania podjętej przeciwko nim decyzji. Jednakże zdecydowana większość państw członkowskich nie wiąże negatywnych skutków prawnych z niestosowaniem ogólnych dyrektyw administracyjnych.

Komentowane standardy wynikajace z rekomendacji zostały stworzone dla zapewnienia wykonywania władzy dyskrecjonalnej w sposób sprawiedliwy, który będzie uniemożliwiał arbitralność podejmowanych rozstrzygnięć oraz nadużywanie przyznanych kompetencji. Jak wynika z powyższej analizy, do stosowania zdecydowanej większości tych zasad zostały stworzone w Polsce odpowiednie ramy prawne. Ich prawidłowa realizacja zależna jest jednak od samych organów stosujących prawo.

\section{Rezolucja Komitetu Rady Ministrów Europy nr (77)31}

\section{z 28 września 1977 r. o ochronie jednostki w sprawach rozstrzyganych aktami organów administracji}

Kolejnym aktem na poziomie unijnym jest rezolucja (zalecenie) z $1977 \mathrm{r}$. , która ustanowiła pewne fundamentalne reguły, jakimi powinno się rządzić każde postępowanie administracyjne na terenie Unii Europejskiej, aby mogło

${ }^{33}$ R. Hauser, O konieczności dyscyplinowania administracji, „Rzeczpospolita” 2011, nr 4, teza nr 1, Lex, nr 130413/1. 
być uznane za odpowiadające regułom „europejskości” ${ }^{44}$. Zasadami ustanowionymi przez rezolucję są:

1) prawo do wysłuchania w sprawie, której rezultatem może być decyzja obciążająca jednostkę obowiązkiem albo ograniczająca jej prawa;

2) prawo do uzyskania informacji o przebiegu sprawy, o dowodach i innych okolicznościach postępowania;

3) prawo do uczestniczenia w prowadzeniu postępowania, które jednostki dotyczy;

4) konieczność uzasadniania decyzji;

5) konieczność zapewnienia odwołania od decyzji.

W kontekście omawianej władzy dyskrecjonalnej należy zwrócić szczególna uwagę na dwa ostatnie punkty: konieczność uzasadniania decyzji oraz zapewnienia od nich odwołania.

Uzasadnienie faktyczne i prawne jest elementem obligatoryjnym każdej decyzji, o czym stanowi art. $107 \S 1$ k.p.a. Od uzasadnienia można odstapić jedynie wyjątkowo, jeśli decyzja w całości uwzględnia żądanie strony. Uzasadnienie rozstrzygnięć dyskrecjonalnych spełnia szczególnie istotną rolę, gdyż umożliwia ich pogłębioną kontrolę. W orzecznictwie podkreśla się, że obowiązek uzasadniania decyzji jest większy w przypadku, gdy organ działał w ramach dyskrecjonalności. Trybunał Konstytucyjny orzekł, że: „Korelatem swobody (uprawnienia dyskrecjonalnego) jest zwiększony obowiązek perswazyjny, znajdujący wyraz w treści uzasadnienia"35. Uzasadnienie w przypadku tych decyzji jest więc szczególnie ważne ze względu na konieczność odtworzenia przez sąd motywów, jakimi kierował się organ przy podejmowaniu konkretnego rozstrzygnięcia. Sąd nie prowadzi postępowania dowodowego w sprawie, a więc jedyną możliwością oceny prawidłowości jego przeprowadzenia przez organ administracji publicznej jest jego odtworzenie poprzez zapoznanie się z uzasadnieniem decyzji. Lakoniczne uzasadnienie takiej decyzji częstokroć będzie konsekwencją niepodjęcia wszystkich możliwych działań zmierzających do dokładnego wyjaśnienia stanu faktycznego sprawy, niewyczerpujacego zebrania i rozpatrzenia materiału dowodowego ${ }^{36}$. Z kolei spójność argumentacji będzie świadczyć o prawidłowości przeprowadzonego postępowania dowodowego oraz o prawidłowości wykładni zastosowanych w sprawie przepisów. Szczegółowe uzasadnienie jest zatem elementem umożliwiającym odróżnienie działania organu w sposób dyskrecjonalny (zgodny z prawem) od działania w sposób dowolny (niezgodny z prawem).

Kolejnym z elementów wskazanych przez rezolucję, a jednocześnie istotnych dla decyzji dyskrecjonalnych jest zapewnienie możliwości odwołania się. Ze względu na charakter takich rozstrzygnięć, które są podejmowane w ramach pewnej swobody, niezbędne jest, aby jednostka mogła się od nich odwołać. Szczególnie należy podkreślić fakt, że powinna być zapewniona możliwość

${ }^{34}$ B. Adamiak, Europeizacja prawa postepowania administracyjnego, w: Z. Janku et al. (red.), Europeizacja polskiego prawa administracyjnego, Wrocław 2005, s. 19.

${ }^{35}$ Wyrok TK z 31 marca 2005 r., SK 26/2002.

36 Por. wyrok WSA w Gorzowie Wlkp. z 23 lutego 2012 r., II SA/Go 8/12. 
kontroli takich decyzji przed organem niezależnym od struktur administracji. Tylko taki organ będzie mógł zapewnić rzetelne i obiektywne rozpatrzenie sprawy. W polskim postępowaniu taką funkcję pełnią sądy, przede wszystkim administracyjne, ale w niektórych sprawach także powszechne (np. w sprawach z zakresu ubezpieczeń społecznych).

\section{Europejski kodeks dobrej administracji}

Prawo do dobrej administracji zostało ustanowione w art. 41 Karty praw podstawowych Unii Europejskiej ${ }^{37}$ przyjętej w 2000 r. Rozwinięcie tego zapisu stanowi przyjęty rok później Europejski kodeks dobrej administracji (dalej: Kodeks), który ustanowił szereg standardów.

W pierwszej kolejności należy zwrócić uwagę na definicję jednostki zawarta $\mathrm{w}$ art. 2 pkt 3 Kodeksu. Jednostkami w świetle prawa unijnego sa zarówno osoby fizyczne, jak i osoby prawne bez względu na to, czy ich miejsce zamieszkania lub zarejestrowanej siedziby znajduje się na terytorium jednego z państw członkowskich. Zatem jednostka to nie tylko osoba fizyczna, ale także każda osoba prawna mogąca być adresatem rozstrzygnięcia organu administracyjnego.

Niewątpliwie ważną zasadą przy rozstrzyganiu spraw w ramach władzy dyskrecjonalnej jest zasada współmierności wyrażona w art. 6 Kodeksu. Stanowi ona, że urzędnik w toku podejmowania decyzji powinien zapewnić współmierność przyjętych działań do obranego celu, w szczególności zaś powinien dokonać wyważenia interesu prywatnego i publicznego. Cele, o których mowa, często wytycza sam ustawodawca, dając im wyraz w preambule ustawy albo w uzasadnieniu jej projektu. Jednocześnie organ stosujący prawo powinien zapoznać się z aksjologią danej regulacji, aby móc z jej uwzględnieniem „miarkować" przewidziane prawem środki tak, aby dysponując luzem decyzyjnym, uwzględnić interes jednostki w jak najszerszym zakresie ${ }^{38}$.

Zasada współmierności została wyrażona w art. 7 § 2 ustawy o postępowaniu egzekucyjnym $\mathrm{w}$ administracji ${ }^{39}$, który stanowi, że organ egzekucyjny stosuje środki egzekucyjne, które prowadzą bezpośrednio do wykonania obowiązku, a spośród kilku takich środków - środki najmniej uciążliwe dla zobowiązanego. Zasada ta znalazła swój wyraz również w polskim postępowaniu administracyjnym. Artykuł 7 k.p.a. in fine stanowi o wyważaniu interesu społecznego i słusznego interesu obywateli. Naczelny Sąd Administracyjny już w 1981 r. stwierdził, że artykuł ten wskazuje, co organy administracji powinny uwzględniać, działając w sferze luzów decyzyjnych ${ }^{40}$. Z kolei w orzecz-

37 Karta praw podstawowych Unii Europejskiej (Dz. Urz. UE C 83/02).

38 J. Świątkiewicz, Europejski Kodeks Dobrej Administracji. Tekst i komentarz o zastosowaniu kodeksu w warunkach polskich procedur administracyjnych, Biuro Rzecznika Praw Obywatelskich, Warszawa 2002, s. 16.

39 Ustawa z 17 czerwca 1966 r. o postępowaniu egzekucyjnym w administracji, t.jedn.: Dz. U. 2012, poz. 1015 ze zm.

${ }^{40}$ Wyrok NSA z 11 czerwca 1981 r., SA 820/81, ONSA 1981, nr 1, poz. 57. 
nictwie unijnego Trybunału Sprawiedliwości zasada współmierności wyraża się w przyznaniu ochrony uzasadnionym oczekiwaniom jednostki (legitimate expectations). Oznacza to, że organ działający w ramach przyznanej mu władzy dyskrecjonalnej dokonuje poważnego naruszenia prawa, jeśli nie uwzględni słusznego interesu obywatela ${ }^{41}$. Koncepcja uzasadnionych oczekiwań wyrosła na gruncie prawa brytyjskiego, w którym przesłanka racjonalności (słuszności) decyduje o zgodności z prawem podjętych rozstrzygnięć ${ }^{42}$.

Istotnym zakazem, który łączy się z omówioną wyżej współmiernościa, jest zakaz nadużywania uprawnień (art. 7 Kodeksu). Zgodnie z nim urzędnik może korzystać z przyznanych mu uprawnień wyłącznie do osiągnięcia celów, dla których uprawnienia te zostały mu powierzone mocą odnośnych przepisów. Standard ten stanowi powtórzenie pierwszego z omawianych wcześniej standardów znajdującego się w rekomendacji nr R (80)2.

Należy też zwrócić uwagę na art. 18 Kodeksu i wyrażony w nim ponownie obowiązek uzasadniania decyzji. Z uwagi na fakt, że szczegółowe uzasadnienie jest elementem umożliwiajacym odróżnienie działania organu w sposób dyskrecjonalny od działania w sposób dowolny, weryfikacji podczas kontroli sądowej decyzji wydanej w ramach luzów decyzyjnych powinno podlegać nie tylko istnienie podstawy prawnej (kompetencji) do wydania rozstrzygnięcia dyskrecjonalnego, ale także proces wydania decyzji i ustalania stanu faktycznego.

Obecnie w Parlamencie Europejskim trwają prace nad uchwaleniem Europejskiego kodeksu postępowania administracyjnego ${ }^{43}$. Akt ten $\mathrm{w}$ zamyśle ma niwelować obecne wady regulacji w zakresie prawa i postępowania administracyjnego na poziomie unijnym, która zdaniem prawodawcy jest zbyt fragmentaryczna i dotyczy jedynie wybranych sektorów ${ }^{44}$. Podkreśla się, że regulacja kodeksowa jest potrzebna przede wszystkim do wdrożenia do postępowań administracyjnych kluczowych zasad opartych na omówionym wyżej prawie do dobrej administracji. Akt ten ma także stanowić próbę wyrównania pozycji prawnej organów i jednostek, gdyż zdaniem prawodawcy unijnego „nadal istnieje zbyt duża luka pomiędzy obywatelami a instytucjami europejskimi” ${ }^{45}$. Wyrównanie tej różnicy ma nastapić m.in. poprzez przyznanie jednostce jak najszerszego zakresu ochrony.

${ }^{41}$ Por. wyrok z 19 maja 1992 r. w sprawach połaczonych C-104/89 i C-37/90 - J. M. Mulder and others and Otto Heinemann v. Council of the European Communities and Commission of the European Communities, w którym Trybunał orzekł o przekroczeniu granic dyskrecjonalności ze względu na naruszenie nadrzędnej zasady prawa, jaka jest zasada ochrony uzasadnionych oczekiwań jednostki.

${ }^{42}$ W. Wade, C. Forsyth, Administrative Law, Oxford University Press, Oxford 2004, s. 208-209.

${ }^{43}$ European Parliament resolution of 15 January 2013 with recommendations to the Commission on a Law of Administrative Procedure of the European Union (2012/2024(INI)).

${ }^{44}$ Law of Administrative Procedure of the European Union, European Added Value Assessment, s. 10.

${ }^{45}$ Ibidem, s. 21. 


\title{
IV. PODSUMOWANIE
}

Ukształtowane w ten sposób standardy w zakresie prawa administracyjnego oraz planowane regulacje ${ }^{46}$ mają na celu stopniowe równoważenie pozycji prawnej jednostki względem organu administracji publicznej. Omówione standardy stosowania uprawnień dyskrecjonalnych szczególnie dobitnie wykazuja, że powinno się przykładać większą wagę do zachowania równowagi między interesem publicznym a respektowaniem powszechnie uznanych praw jednostki ${ }^{47}$. Potwierdza to również orzecznictwo Trybunału Sprawiedliwości Unii Europejskiej. W wyrokach Trybunału wielokrotnie podkreślano, że traktaty ustanowiły nowy porządek międzynarodowy, w którym państwa zredukowały swoje suwerenne prawa, a podmiotami porządku prawnego sa nie tylko państwa członkowskie, ale przede wszystkim pochodzace z nich jednostki ${ }^{48}$.

Aktualny kierunek zmian zachodzacych na poziomie unijnym charakteryzujacy się szybkim rozrostem regulacji prawnych, w których centrum została postawiona jednostka, a nie państwo członkowskie i jego organy, pokazuje, że Unia Europejska z konfederacji stopniowo przekształca się w państwo federacyjne.

mgr Maria Jędrzejczak

Uniwersytet im. Adama Mickiewicza w Poznaniu

maria.j@amu.edu.pl

\section{THE IMPACT OF EUROPEANISATION ON THE STANDARDS OF PROTECTION OF AN INDIVIDUAL AGAINST THE DISCRETIONARY POWER OF PUBLIC ADMINISTRATION}

\author{
Sum mary
}

This article presents the concept of discretion in Polish administrative law and EU law. The inequality of parties in an administrative law relationship is increased by existence of administrative discretion. The legal situation of an individual is weaker when the administrative body has clearance decision-making. This problem has also been reflected in the planned regulation and standards of the EU legislation in the field of administrative law (Law of Administrative Procedure of the European Union) designed to protect individuals. It is recommended that a balance between the public interest and the legitimate interests of the party be maintained. The Court of Justice of the European Union pointed out that in the international order it is not only Member States, but also individuals who are subject to protection.

${ }^{46}$ Europejski kodeks postępowania administracyjnego.

${ }^{47}$ J. Łętowski, Co dalej z prawem administracyjnym, w: A. Błaś (red.), Przeobrażenia we wspótczesnym prawie administracyjnym i w nauce administracji, „Przegląd Prawa i Administracji”, t. 38, Wrocław 1997, s. 144.

${ }_{48}$ Por. wyroki: z 5 lutego 1963 r. w sprawie 26/62 - Van Gend \& Loos; z 15 lipca 1964 r. w sprawie 6/64 - Costa oraz z 19 listopada 1991 r. w sprawach połączonych C-6/90 i C-9/90 - Francovich $i$ in. Podobnie: P. Daranowski, Kilka uwag o prawach jednostki w Unii Europejskiej /Wspólnocie Europejskiej, w: M. Seweryński (red.) Studia prawno-europejskie, Łódź 1996, s. 81. 